\title{
Deskripsi Kemampuan Pemecahan Masalah Matematika Melalui Pembelajaran Daring pada Materi Persamaan Kuadrat
}

\author{
Siti Zakiyah ${ }^{1}$, Kartin Usman' ${ }^{2}$, Adelia Pratiwi Gobel ${ }^{3 *}$ \\ 1,2,3 Jurusan Matematika, Fakultas MIPA, Universitas Negeri Gorontalo, \\ Jl. Prof. Dr. Ing. B. J. Habibie, Tilongkabila, Kabupaten Bone Bolango, Gorontalo 96119, Indonesia
}

\begin{abstract}
INFO ARTIKEL ABSTRAK

* Penulis Korespondensi. Email: gobeladelia@gmail.com

Diterima:

20 Maret 2021

Disetujui:

29 Maret 2021

Online

31 Maret 2021

Penelitian ini bertujuan untuk mendeskripsikan kemampuan pemecahan masalah siswa pada materi persamaan kuadrat melalui pembelajaran daring. Penelitian ini dilaksanakan di SMP Negeri 10 Gorontalo dengan metode deskriptif yang melibatkan 21 orang siswa sebagai sampel penelitian yang dipilih dengan teknik purposive sampling. Data penelitian ini diperoleh dari tes kemampuan pemecahan masalah dengan melibatkan 4 indikator, yaitu : (1) memahami masalah, (2) membuat strategi, (3) melaksanakan strategi dan (4) menginterpretasikan hasil. Data yang diperoleh dianalisis dalam bentuk persentase kemudian dikategorikan berdasarkan kriteria penilaian. Hasil analisis menunjukkan bahwa kemampuan pemecahan masalah matematika siswa termasuk dalam kategori rendah yang ditunjukkan dengan persentase skor yang dicapai oleh siswa adalah sebesar $60,89 \%$.
\end{abstract}

Format Sitasi: S. Zakiyah, K. Usman, and A.P. Gobel, “Deskripsi Kemampuan Pemecahan Masalah Matematika melalui Pembelajaran Daring pada Materi Persamaan Kuadrat, "Jambura J. Math. Educ., vol. 2, no. 1, pp.28-35, 2021

Lisensi:

JMathEdu is licensed under a Creative Commons AttributionNonCommercial 4.0 International License

Kata Kunci: Kemampuan Pemecahan Masalah; Persamaan Kuadrat; Pembelajaran Daring

\section{ABSTRACT}

This research aims to describe students' mathematical problem-solving ability in quadratic equation material through online learning. This research was conducted at SMP Negeri 10 Gorontalo with a descriptive method involving 21 students as the research sample selected by purposive sampling technique. The data of this research were obtained from the problemsolving ability test involving 4 indicators, which are: (1) understand the problems, (2) make a strategy, (3) implement the strategy, and (4) interpret the results. The data obtained were analyzed in the form of a percentage and then categorized based on the assessment criteria. The results of the analysis showed that the students' mathematical problem-solving abilities were included in the low category as indicated by the percentage score achieved by the students was $60.89 \%$.

Keywords: Problem Solving Ability, Quadratic Equation, Online Learning

Copyright (C) 2021

Jambura Journal of

Mathematics Education

\section{Pendahuluan}

Pandemi yang disebabkan oleh menyebarnya virus Covid-19 menyebabkan pemerintah mengeluarkan kebijakan physical distancing, sehingga semua kegiatan yang melibatkan orang banyak dalam satu tempat dihentikan sementara untuk meminimalisir potensi penyebaran virus tersebut. Pemerintah melalui Kementrian 
Pendidikan dan kebudayaan mengeluarkan surat edaran No.4 tentang Pelaksanaan Kebijakan Pendidikan Dalam Masa Darurat Penyebaran Corona Virus Disease (Covid19) terhitung mulai 24 Maret 2020 menghimbau kegiatan pembelajaran di sekolahsekolah dihentikan sementara karena termasuk kegiatan yang melibatkan banyak orang [1]. Pembelajaran daring (dalam jaringan) menjadi pilihan pada masa pandemi ini agar proses pembelajaran bisa terus dilakukan selama penerapan kebijakan physical distancing ini. SMP Negeri 10 Gorontalo sebagai salah satu sekolah menengah pertama di Kota Gorontalo yang turut dalam penerapan kebijakan pembelajaran daring. Dalam proses pembelajaran daring, SMP Negeri 10 Gorontalo menggunakan bantuan platform/aplikasi Google Meet, Google Classroom, Google Form dan Whatsapp.

Walaupun proses pembelajaran tidak berlangsung secara konvesional (tatap muka), namun perlu diperhatikan bahwa tujuan pembelajaran matematika harus tetap tercapai. Berdasarkan Permendikbud Nomor 58 Tahun 2014 tentang tujuan pembelajaran matematika satu dari delapan tujuan pembelajaran matematika adalah agar siswa mempunyai kemampuan pemecahan masalah matematika. Hal ini sejalan dengan standar kemampuan matematis yang ditetapkan oleh National Council of Teachers of Mathematics (NCTM) yang salah satunya adalah kemampuan pemecahan masalah (problem solving). Upaya-upaya pengkajian terhadap kemampuan siswa pada dasarnya banyak dilakukan seperti kemampuan komunikasi matematis [2], kemampuan berpikir kreatif [3], ataupun kemampuan penalaran [4][5], sebagaimana halnya kemampuan pemecahan masalah. Namun terkadang, setiap satuan pendidikan memiliki persoalan yang berbeda-beda yang butuh penangkajian dan penanganan khusus, seperti halnya yang terjadi di SMP Negeri 10 Gorontalo.

Hasil wawancara dan observasi bersama guru mata pelajaran matematika memberikan informasi bahwa siswa masih mengalami kendala untuk menyelesaikan soal yang berkaitan dengan pemecahan masalah. Kendala yang dialami siswa yaitu menerjemahkan informasi dalam soal kedalam bahasa matematika atau memodelkan masalah ke dalam kalimat matematika. Sedang pada masa pembelajaran daring ini, guru lebih sering memberikan soal rutin kepada siswa berupa soal latihan biasa yang banyak terdapat dalam buku teks dan hanya digunakan untuk dapat melatih siswa menggunakan prosedur atau metode yang sedang dipelajari di kelas. Akibatnya, kemampuan pemecahan masalah siswa tidak terasah karena tidak terbiasa mengerjakan soal pemecahan masalah. Pada materi persamaan kuadrat yang banyak berkaitan dengan kehidupan sehari-hari, kesulitan siswa diawali dari kurangnya penguasaan siswa pada materi prasyarat, yaitu materi operasi aljabar dimana siswa kurang mampu untuk mengoperasikan bilangan positif dan bilangan negatif. Selain itu, siswa sulit untuk menyelesaikan soal dengan menggunakan metode pemfaktoran dan metode menyempurnakan akar kuadrat sehingga siswa lebih sering menggunakan metode $a b c$.

Berbagai penelitian yang berkaitan dengan pembelajaran daring guna menganalisis proses pembelajaran daring ditengah pandemi covid-19 dapat ditemukan pada [6][7], termasuk penelitian yang secara khusus membahas efektivitas pembelajaran daring pada mata pelajaran matematika yang dapat dilihat pada [8]-[10]. Selain itu penelitian yang mengkaji kemampuan pemecahan masalah matematika juga sudah banyak dilakukan sebelumnya, penelitian yang membahas tentang analisis kemampuan pemecahan masalah matematika dapat dilihat pada [11]-[13]. Disamping itu, terdapat penelitian yang berkaitan dengan upaya untuk meningkatkan kemampuan pemecahan 
masalah matematika yang dapat dilihat pada [14][15]. Adapun penelitian yang terkait dengan materi persamaan kuadrat dapat ditemukan pada [16][17]. Dari banyaknya penelitian yang telah disebutkan sebelumnya, menariknya belum ada penelitian yang membahas mengenai kemampuan pemecahan siswa selama proses pembelajaran daring, utamanya pada materi persamaan kuadrat.

Oleh karena itu, dalam artikel ini dilakukan analisis terhadap kemampuan pemecahan masalah matematika pada materi persamaan kuadrat melalui pembelajaran daring. Peneliti merasa perlu melakukan penelitian ini karena kemampuan pemecahan masalah adalah salah satu tujuan penting yang harus dicapai dalam proses pembelajaran matematika walaupun pada masa pandemi ini proses pembelajaran berubah dari konvesional (tatap muka) menjadi daring atau secara virtual. Hasil penelitian ini diharapkan dapat memberikan informasi kepada guru dan pihak sekolah terkait kemampuan pemecahan masalah siswa siswa melalui pembelajaran daring.

\section{Metode}

Penelitian ini menggunakan metode penelitian deskriptif untuk mendeskripsikan kemampuan pemecahan masalah siswa pada materi persamaan kuadrat melalui pembelajaran daring. Penelitian ini melibatkan 21 orang siswa sebagai sampel penelitian yang ditentukan menggunakan teknik purposive sampling. Data yang digunakan adalah data hasil skor tes kemampuan pemecahan masalah yang diperoleh melalui tes essay. Data diperoleh dengan cara memberikan instrumen tes kemampuan pemecahan masalah yang berbentuk tes essay pada materi persamaan kuadrat. Sebelum instrumen tersebut digunakan, terlebih dahulu instrumen tersebut diuji validitas dan reliabilitasnya. Data hasil tes kemampuan pemecahan masalah siswa dianalisis menggunakan analisis persentase. Untuk mengetahui persentase kemampuan pemecahan masalah digunakan rumus berikut:

$$
\text { presentase }=\frac{\text { skor yang diperoleh }}{\text { skor maksimum }} \times 100 \%
$$

Selanjutnya skor hasil tes kemampuan pemecahan masalah siswa dikategorikan berdasarkan kriteria penilaian di SMP Negeri 10 Kota Gorontalo yang mengacu pada Tabel 1 .

Tabel 1. Kategori kemampuan pemecahan masalah siswa berdasarkan kriteria penilaian di SMP Negeri 10 Gorontalo

\begin{tabular}{cl}
\hline Persentase $(\%)$ & Kategori \\
\hline $92-100$ & Sangat Tinggi \\
$82-91$ & Tinggi \\
$72-81$ & Sedang \\
$\leq 71$ & Rendah \\
\hline
\end{tabular}

\section{Hasil dan Pembahasan}

\subsection{Hasil}

Hasil penelitian yang ditunjukan melalui tes kemampuan pemecahan masalah dengan 4 indikator yaitu 1) memahami masalah, 2) membuat strategi, 3) melaksanakan strategi 
dan 4) menginterpretasikan hasil ditunjukkan menggunakan diagram batang pada Gambar 1.

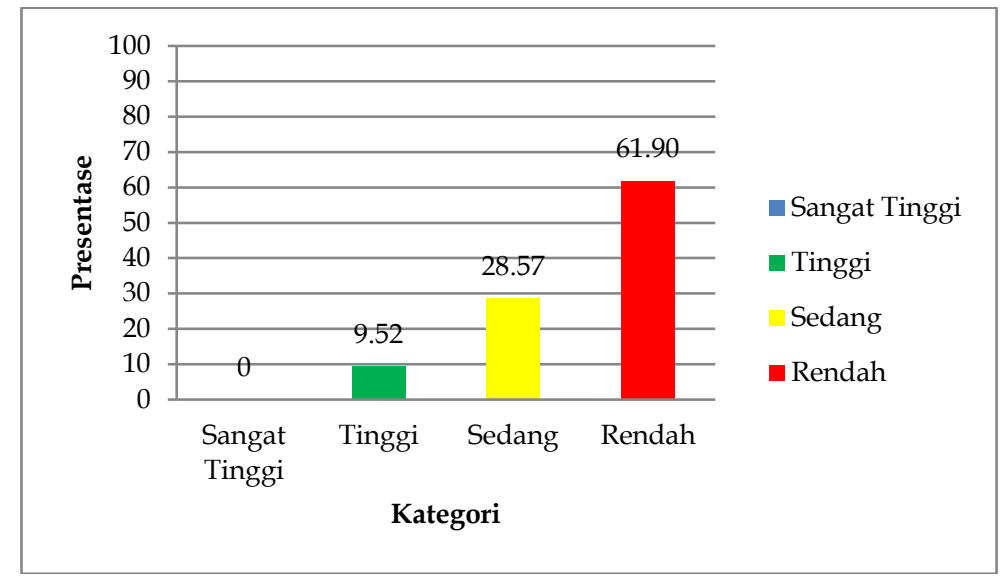

Gambar 1. Persentase kemampuan pemecahan masalah siswa

Gambar 1 menunjukkan bahwa persentase kemampuan pemecahan masalah siswa adalah $0 \%$ siswa tergolong kategori sangat tinggi, 9,52\% siswa tergolong kategori tinggi, 28,57\% siswa tergolong kategori sedang 61,90\% siswa tergolong kategori rendah. Siswa mencapai skor 844 dari total skor 1.386, artinya kemampuan pemecahan masalah siswa mencapai 60,89\% dan tergolong kategori rendah.

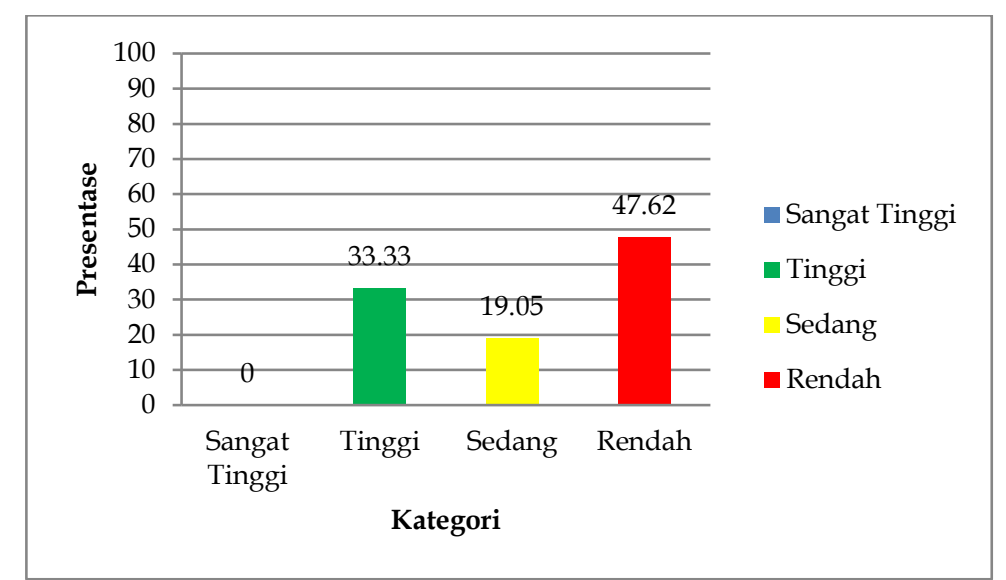

Gambar 2. Persentase kemampuan siswa pada indikator I memahami masalah

Gambar 2 menunjukkan bahwa persentase kemampuan siswa pada indikator I memahami masalah adalah $0 \%$ siswa tergolong kategori sangat tinggi, 33,33\% siswa tergolong kategori tinggi, 19,05\% siswa tergolong kategori sedang dan 47,62\% siswa tergolong kategori rendah. Siswa mencapai skor 208 dari total skor 378, artinya kemampuan siswa pada indikator I memahami masalah mencapai 55,03\% dan tergolong kategori rendah. 
S. Zakiyah, dkk | Deskripsi Kemampuan Pemecahan Masalah Matematika melalui ...

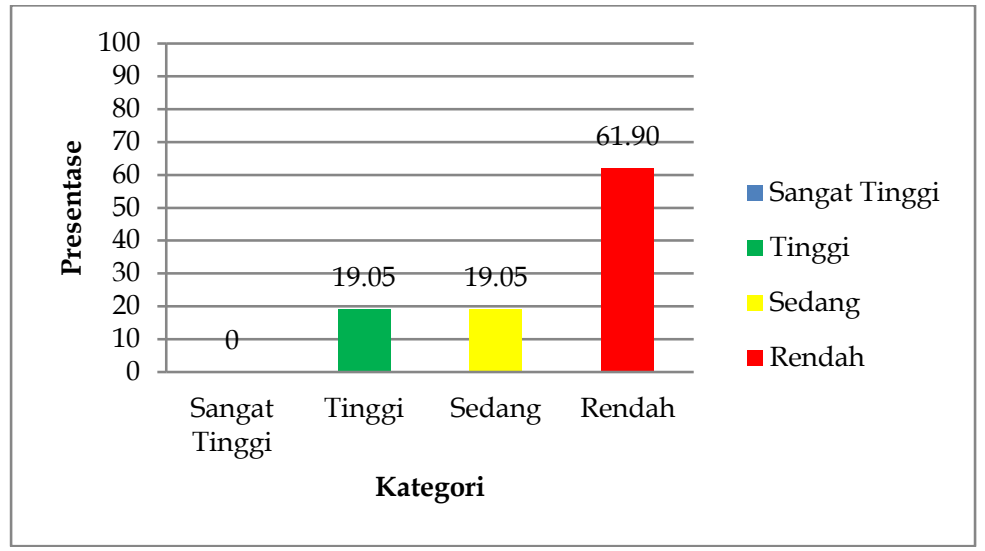

Gambar 3. Persentase kemampuan siswa pada indikator II membuat strategi

Gambar 3 menunjukkan bahwa persentase kemampuan siswa pada indikator II membuat strategi adalah $0 \%$ siswa tergolong kategori sangat tinggi, 19,05\% tergolong kategori tinggi, 19,05\% siswa tergolong kategori sedang dan 61,90\% siswa tergolong kategori rendah. Siswa mencapai skor 252 dari total skor 378, artinya kemampuan siswa pada indikator II membuat strategi mencapai $66,67 \%$ dan tergolong kategori rendah.

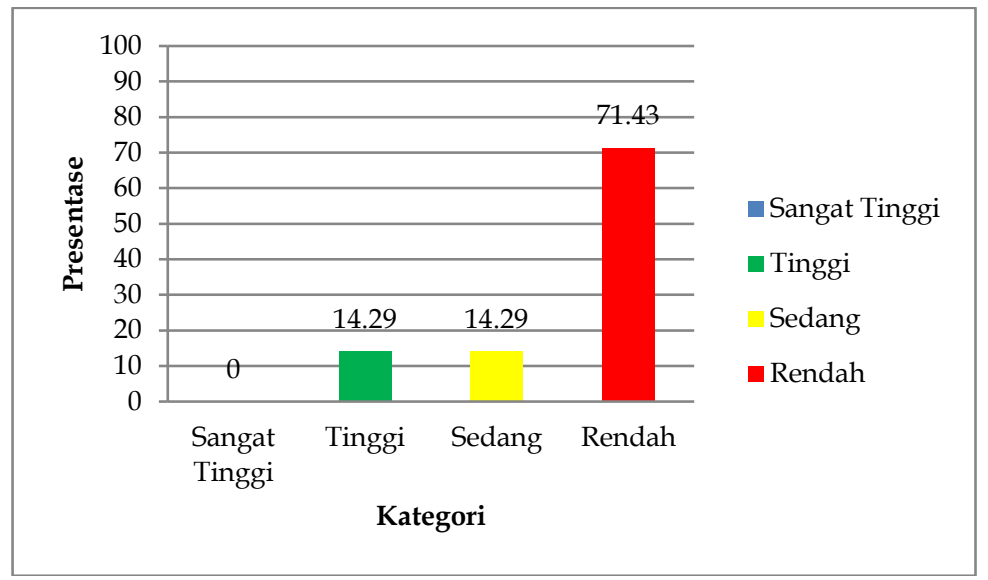

Gambar 4. Persentase kemampuan siswa pada indikator III melaksanakan strategi

Gambar 4 menunjukkan bahwa persentase kemampuan siswa pada indikator III melaksanakan strategi adalah $0 \%$ siswa tergolong kategori sangat tinggi, 14,29\% siswa tergolong kategori tinggi, 14,29\% siswa tergolong kategori sedang dan 71,43\% siswa tergolong kategori rendah. Siswa mencapai skor 238 dari total skor 378, artinya kemampuan siswa pada indikator III melaksankan strategi mencapai 62,96\% dan tergolong kategori rendah. 


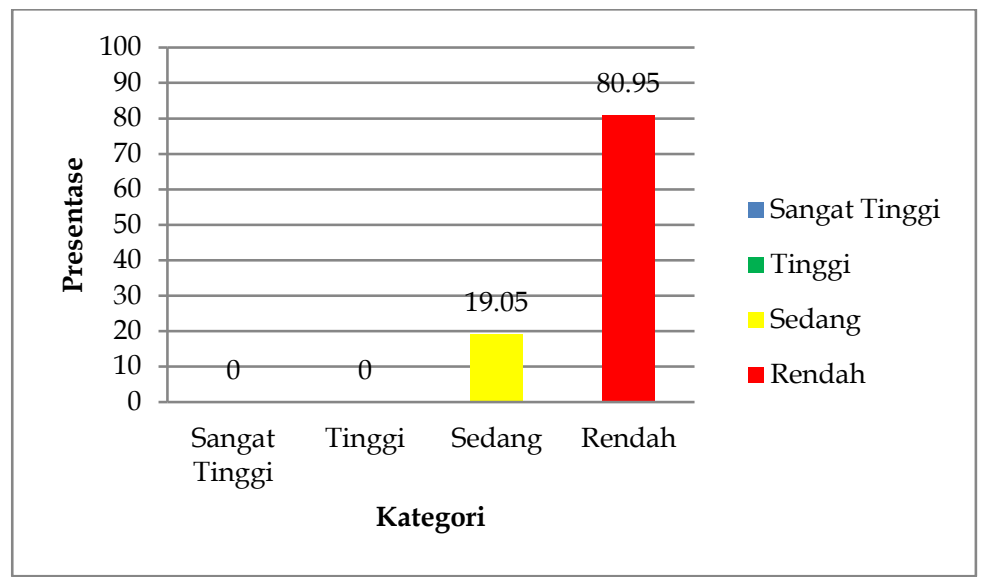

Gambar 5. Persentase kemampuan siswa pada indikator IV menginterpretasikan hasil

Gambar 5 menunjukkan bahwa persentase kemampuan siswa pada indikator IV menginterpretasikan hasil adalah $0 \%$ siswa tergolong kategori sangat tinggi, $0 \%$ siswa tergolong kategori tinggi, 19,05\% siswa tergolong kategori sedang dan 80,95\% siswa tergolong kategori rendah. Siswa mencapai skor 133 dari total skor 252, artinya kemampuan siswa pada indikator IV menginterpretasikan hasil mencapai 52,78\% dan tergolong kategori rendah.

\subsection{Pembahasan}

Berdasarkan hasil tes kemampuan pemecahan masalah matematika yang dilakukan di kelas IX SMP Negeri 10 Gorontalo, siswa terbagi menjadi 3 tingkatan kategori yaitu kategori tinggi, kategori sedang dan kategori rendah.

\subsubsection{Kemampuan Pemecahan Masalah Kategori Tinggi}

Siswa yang tergolong kategori tinggi adalah siswa yang dapat menyelesaikan beberapa soal dengan benar namun belum semuanya tepat. Siswa yang tergolong pada kategori ini adalah siswa yang dapat mencapai hampir semua indikator kemampuan pemecahan masala pada penelitian ini. Siswa sudah mampu untuk menuliskan dengan benar apa yang diketahui dan ditanyakan dari soal tetapi pada beberapa soal siswa cenderung hanya menuliskan sebagian unsur yang diketahui karena siswa sudah paham dengan soal yang diberikan, mampu menuliskan model matematika dari soal dan menentukan rumus yang diperlukan untuk menyelesaikan soal dengan benar, mampu melakukan perhitungan untuk menemukan jawaban untuk menyelesaikan soal dengan benar, dan mampu membuat kesimpulan dari jawaban yang diperoleh dengan benar walaupun pada beberapa soal masih ada sedikit kesalahan yang dilakukan oleh siswa.

\subsubsection{Kemampuan Pemecahan Masalah Kategori Sedang}

Siswa yang tergolong pada kategori sedang adalah siswa yang dapat menyelesaikan beberapa soal dengan benar namun masih terdapat beberapa kekeliruan. Siswa yang tergolong pada kategori ini adalah siswa yang dapat mencapai setengah atau lebih dari setengah indikator kemampuan pemecahan masalah pada penelitian ini. Siswa mampu untuk menuliskan dengan benar apa yang diketahui dan ditanyakan dari soal, tetapi pada beberapa soal siswa hanya menuliskan sebagian unsur yang diketahui dari soal, mampu menuliskan model matematika dari soal dan menentukan rumus yang 
diperlukan untuk menyelesaikan soal dengan benar, mampu melakukan perhitungan untuk menemukan jawaban untuk menyelesaikan soal dengan benar, dan mampu membuat kesimpulan dari jawaban yang diperoleh dengan benar, namun terdapat beberapa kekeliruan yang dilakukan siswa pada sebagian soal.

\subsubsection{Kemampuan Pemecahan Masalah Kategori Sedang}

Siswa yang tergolong pada kategori rendah adalah siswa yang tidak bisa menyelesaikan soal dengan benar, bahkan tidak mengerjakan sama sekali beberapa soal lainnya. Siswa yang tergolong pada kategori ini adalah siswa yang tidak dapat mencapai hampir semua indikator kemampuan pemecahan masalah pada penelitian ini. Siswa kurang mampu untuk menuliskan apa yang diketahui dan ditanyakan dari soal, dimana pada beberapa soal siswa hanya menuliskan sebagian unsur yang diketahui dari soal atau hanya menuliskan kembali soal yang diberikan, bahkan tidak menuliskan apa yang diketahui dan ditanyakan dari soal, kurang mampu untuk menuliskan model matematika dari soal dan menentukan rumus yang diperlukan untuk menyelesaikan soal dimana pada sebagian besar soal salah bahkan tidak menuliskannya sama sekali, kurang mampu melakukan perhitungan untuk menemukan jawaban untuk menyelesaikan soal dimana pada sebagian besar soal salah bahkan tidak melakukan perhitungan sama sekali, dan kurang mampu membuat kesimpulan dari jawaban yang diperoleh dengan benar, dimana pada sebagian besar soal membuat kesimpulan salah bahkan tidak membuat kesimpulan sama sekali.

\section{Kesimpulan}

Secara keseluruhan kemampuan pemecahan masalah matematika siswa kelas IX SMP Negeri 10 Gorontalo pada materi persamaan kuadrat melalui pembelajaran daring tergolong pada kategori rendah dengan mencapai persentase 60,89\%. Kemampuan pemecahan masalah matematika siswa kelas IX SMP Negeri 10 Gorontalo pada materi persamaan kuadrat melalui pembelajaran daring digolongkan pada 3 kategori yaitu kategori tinggi sebanyak 2 orang siswa dengan presentasi 9,52\% ,kategori sedang sebanyak 9 orang siswa dengan presentasi $28,57 \%$, dan kategori rendah sebanyak 10 orang siswa dengan presentasi 61,90\%. Faktor-faktor yang mempengaruhi kemampuan pemecahan masalah siswa pada materi persamaan kuadrat yaitu kurang maksimalnya proses pembelajaran daring, kesulitan siswa membuat model matematika dari soal, kurangnya penguasaaan materi prasyarat dan kurangnya latihan soal-soal non rutin bagi siswa.

\section{Referensi}

[1] W. Wiryanto, "Proses Pembelajaran Matematika Di Sekolah Dasar Di Tengah Pandemi Covid-19," Jurnal Review Pendidikan Dasar: Jurnal Kajian Pendidikan dan Hasil Penelitian.,vol.6 , no.2, 2020.

[2] S. Wahyuni, M. Yati, and A. Fadila, "Pengembangan Modul Matematika Berbasis REACT terhadap Kemampuan Komunikasi Matematis Peserta Didik," Jambura J. Math. Educ., vol. 1, no. 1, pp. 1-12, Feb. 2020.

[3] C. Magelo, E. Hulukati, and I. Djakaria, "Pengaruh Model Pembelajaran OpenEnded terhadap Kemampuan Berpikir Kreatif Matematik Ditinjau dari Motivasi Belajar," Jambura J. Math., vol. 2, no. 1, pp. 15-21, Dec. 2019. 
[4] N. A. Yunus, E. Hulukati, and I. Djakaria, "Pengaruh Pendekatan Kontekstual Terhadap Kemampuan Penalaran Matematis Ditinjau dari Gaya Kognitif Peserta Didik," Jambura J. Math., vol. 2, no. 1, pp. 30-38, Dec. 2019.

[5] S. Khadijah, S. Ismail, and R. Resmawan, "Pengembangan Bahan Ajar Berbasis Penalaran pada Materi Sudut Pusat dan Sudut Keliling Lingkaran," Al-Khwarizmi J. Pendidik. Mat. dan Ilmu Pengetah. Alam, vol. 8, no. 1, pp. 1-12, Apr. 2020.

[6] N. M. D. Ardiyanti, G. A. Mahayukti and I. M. Sugiarta, "Evaluasi Proses Pembelajaran Matematika Secara Daring Di Sman Kota Singaraja," Jurna IKA., vol.18, no.2, pp.136-157, 2020.

[7] S. D. Handayani and A. Irawan, "Pembelajaran Matematika Dimasa Pandemic Covid-19 Berdasarkan Pendekatan Matematika Realistik," Jurna Math Educator Nusantara., vol.6, no.2, pp.179-189, 2020.

[8] B. Kusumaningrum dan Z. Wijayanto, "Apakah Pembelajaran Matematika Secara Daring Efektif? (Studi Kasus pada Pembelajaran Selama Masa Pandemi Covid-19),"Jurnal Matematika Kreatif-Inovatif., vol. 11, no.2, pp.136-142. 2020.

[9] A. Ahmad, F. Nuzula, and K. Makky, "Efektivitas Pembelajaran Daring Dengan Menggunakan Google Classroom Pada Mata Pelajaran Matematika Di Madrasah Aliyah Darul Falah Batu Jangkih," El-Hikam Journal of Education and Religious Studies., vol.13. no.1. pp. 67-82, 2020.

[10] M. Mustakim, "Efektivitas Pembelajaran Daring Menggunakan Media Online Selama Pandemi Covid-19 Pada Mata Pelajaran Matematika," Al asma: Journal of Islamic Education., vol.2, no.1, pp.1-12, 2020.

[11] N. S. Mulyani and F. Sulistiani, "Analisis Kemampuan Pemecahan Masalah Matematis Dan Minat Belajar Siswa SMA di Bandung Barat". Journal On Education., vol.1, no.4, pp. 634-643, 2019.

[12] L. W Nengsih, S. Susiswo and C. Sa'dijah, “Kemampuan Pemecahan Masalah Matematika Siswa Sekolah Dasar dengan Gaya Kognitif Field Dependent". Jurnal Pendidikan: Teori, Penelitian, dan Pengembangan., vol.4, no.2, pp. 143-148, 2019.

[13] S. Arifin K. Kartono and I. Hidayah, "Analisis Kemampuan Pemecahan Masalah Pada Model Problem Based Learning Disertai Remedial Teaching,"Jurnal EduMa., vol.8 no.1, pp. 85-97, Jul. 2019.

[14] S. A. Yusuf, N. Abbas and A. Kaku, "Meningkatkan Kemampuan Pemecahan Masalah Dan Komunikasi Matematika Melalui Model Pembelajaran Kooperatif Tipe Think-TalkWrite (Ttw) Pada Materi Program Linear Di Kelas X Smk Negeri 1 Gorontalo Utara," JPs: Jurnal Riset dan Pengembangan Ilmu Pengetahuan., vol.2, no.1, pp.166-171, Feb. 2017.

[15] M. D. Nasution and W. Oktaviani, "Pengembangan Perangkat Pembelajaran Matematika Berbasis Masalah Untuk Meningkatkan Kemampuan Pemecahan Masalah Siswa Smp Pab 9 Klambir V T.P 2019/2020," Journal Mathematics Education Sigma (JMES)., vol.1, no.1, 2020.

[16] N. Kesumayanti and R. W. Y. Putra, "Pengembangan Bahan Ajar Materi Persamaan Kuadrat Berbantuan Rumus Cepat," Jurnal Edukasi dan Sains Matematika (JES-MAT)., vol.3, no.2, pp.125-138, Sept. 2017.

[17] M. F. Fatoni, D. Dafik and A. Fatahillah, "Pengembangan Media Pembelajaran Interaktif Online Menggunakan Kelaskita Berbantuan Software Geogebra Pada Materi Persamaan Kuadrat," Jurnal Kadikma., vo.8 , no.2, pp. 24-33, Aug. 2017. 